\title{
Understanding of Pharmacy Students towards Antibiotic Use, Antibiotic Resistance and Antibiotic Stewardship Programs: A Cross-Sectional Study from Punjab, Pakistan
}

\author{
Khezar Hayat ${ }^{1,2,3,4}$, Shazia Jamshed ${ }^{5,6}$, Meagen Rosenthal ${ }^{7} \mathbb{D}$, Noman U1 Haq ${ }^{8}$, Jie Chang ${ }^{1,2,3} \mathbb{D}^{\mathbb{D}}$, \\ Muhammad Fawad Rasool ${ }^{9} \mathbb{D}^{\text {, }}$ Usman Rashid Malik 1,2,3 ${ }^{\mathbb{D}}$, Anees Ur Rehman 9 (D), Kashif Maqbool Khan 4 \\ and Yu Fang 1,2,3,*
}

1 Department of Pharmacy Administration and Clinical Pharmacy, School of Pharmacy, Xi'an Jiaotong University, Xi'an 710061, China; khezar.hayat@uvas.edu.pk (K.H.); jiechang@xjtu.edu.cn (J.C.); usmanmalik_ucp@hotmail.com (U.R.M.)

2 Center for Drug Safety and Policy Research, Xi'an Jiaotong University, Xi'an 710061, China

3 Shaanxi Centre for Health Reform and Development Research, Xi'an 710061, China

4 Institute of Pharmaceutical Sciences, University of Veterinary and Animal Sciences, Lahore 54000, Pakistan; Kashif.maqbool@uvas.edu.pk

5 Department of Clinical Pharmacy and Practice, Faculty of Pharmacy, Universiti Sultan Zainal Abidin, Terengganu 22200, Malaysia; shaziajamshed@unisza.edu.my

6 Qualitative Research-Methodological Application in Health Sciences Research Group, Kulliyyah of Pharmacy, International Islamic University Malaysia (IIUM), Kuantan 25200, Malaysia

check for updates

Citation: Hayat, K.; Jamshed, S.; Rosenthal, M.; Haq, N.U.; Chang, J.; Rasool, M.F.; Malik, U.R.; Rehman, A.U.; Khan, K.M.; Fang, Y. Understanding of Pharmacy Students towards Antibiotic Use, Antibiotic Resistance and Antibiotic Stewardship Programs: A Cross-Sectional Study from Punjab, Pakistan. Antibiotics 2021, 10, 66. https://doi.org/10.3390/antibiotics 10010066

Received: 28 December 2020 Accepted: 8 January 2021 Published: 12 January 2021

Publisher's Note: MDPI stays neutral with regard to jurisdictional clai$\mathrm{ms}$ in published maps and institutional affiliations.

Copyright: (C) 2021 by the authors. Licensee MDPI, Basel, Switzerland. This article is an open access article distributed under the terms and conditions of the Creative Commons Attribution (CC BY) license (https:// creativecommons.org/licenses/by/ $4.0 /)$.
7 Department of Pharmacy Administration, School of Pharmacy, University of Mississippi, Oxford, MS 38677, USA; mmrosent@olemiss.edu

8 Department of Pharmacy Practice, Faculty of Pharmacy, University of Balochistan, Quetta 87900, Pakistan; nomanhaq79@gmail.com

9 Department of Pharmacy Practice, Faculty of Pharmacy, Bahauddin Zakariya University, Multan 60800, Pakistan; fawadrasool@bzu.edu.pk (M.F.R.); aneesurrehmanr90@gmail.com (A.U.R.)

* Correspondence: yufang@mail.xjtu.edu.cn; Tel.: +86-29-8265-5132 or +86-185-9197-0591; Fax: +86-29-8265-5424

Abstract: Antibiotic resistance (ABR) is a significant issue for public health globally. An adequate understanding of ABR and the approaches used to tackle ABR, including antibiotic stewardship programs, are vital. This study aimed to get an insight into antibiotic use, ABR, and antibiotic stewardship programs among pharmacy students of Punjab, Pakistan. This multicenter study was undertaken among final (fifth) year undergraduate pharmacy students of 7 universities of Punjab, Pakistan. A paper-based self-administered questionnaire comprising 48-items was utilized for data collection. Descriptive and inferential statistics were employed for data analysis. This study included a total of 296 respondents with a response rate of $85.8 \%$. Most of the students had an average understanding of antibiotic use (59.8\%), ABR (42.6\%), ABR mechanisms (48.0\%), and factors of ABR $(51.7 \%)$. Only $21.6 \%$ of students have heard about antibiotic stewardship programs. More than half of the students believed that educating and training healthcare professionals (53.4\%) and medical students $(57.8 \%)$ about the prescribing and judicial usage of antibiotics could reduce the ABR burden. The awareness of most of the pharmacy students about certain aspects of antibiotic use, ABR, and stewardship programs was suboptimal.

Keywords: antibiotic use; antibiotic resistance; stewardship programs; pharmacy students; knowledge

\section{Introduction}

Antibiotics are used to treat multiple infections due to their inherited ability to restrict the growth of or killing pathogenic microorganisms [1]. However, the continuous irrational, and injudicious use of antibiotics has led to antibiotic resistance (ABR). ABR is a silent tsunami affecting every part of the globe [2]. It has significant implications for healthcare 
spending due to the resulting increase in morbidity and mortality. Every year, nearly 2 million people are affected by resistant infections causing the death of 23,000 patients with a loss of 55 billion USD in the United States (US) [3]. Likewise, 25,000 deaths and 1.5 billion euros are lost in Europe each year [4]. The catastrophic effects attributed to ABR are continuously increasing due to the unavailability of new antibiotics.

The injudicious use of antibiotics in community and hospital settings is a significant driver to increase the ABR problem globally. Studies have shown that $20 \%$ to $50 \%$ of antibiotics prescribed in hospitals are inappropriate [3]. Similarly, more than half of the antibiotics dispensed from community pharmacies are irrational [5]. The situation of ABR in developing countries is worse owing to the climbing incidence of infectious diseases, lack of adequate knowledge among healthcare professionals, insufficient training, inadequate diagnostic facilities, lack of standard treatment guidelines, and antibiotic sale without prescription $[6,7]$.

In this context, adequate knowledge of healthcare professionals about rational antibiotic use and antimicrobial resistance (AMR) prevention could play a significant role in limiting ABR momentum and sustaining the effectiveness of antibiotics $[8,9]$. One of the most integral elements of the World Health Organization (WHO) global action plan to manage ABR is to enhance understanding and awareness about antibiotics among healthcare professionals and the public by effective education, training, and communication [10]. The education and training about appropriate antibiotic use during undergraduate education have a positive impact on the attitude and behavior of healthcare professionals regarding the use of antibiotics [11]. Thus, this training is paramount for doctors, pharmacists, and nurses.

The role of pharmacists in medicine use, including managing ABR through antibiotic stewardship programs (programs that work in collaboration with healthcare professionals aiming to improve patient outcomes by minimizing antibiotic resistance, therapy cost, and risk of resistant infections), is manifested in previously published research [12-14]. Education and adequate pharmacists' training could modify the behavior of doctors, nurses, and consumers as they are the most accessible professionals in the community [13,15]. The professional practice of pharmacists could become substandard in some developing countries, including Pakistan, China, and India if they have insufficient training and education; as a consequence, pharmacists may recommend and supply antibiotics inappropriately [16,17]. Pharmacists with comprehensive education and training on AMR and stewardship programs could play a leading role in changing the community's behavior about antibiotic use and ABR [18].

Pakistan is a developing country where the supply of antibiotics is regulated by wellestablished legislation, and antibiotics can only be dispensed with a valid prescription written by a medical practitioner [19]. A pharmacist needs to complete a five-year Pharm D (Doctor of Pharmacy) program before practicing [20]. It is expected that pharmacy students will be well trained to address the health-related issues of the public. However, little is known about pharmacy students' understanding of antibiotic use, antibiotic resistance, and antibiotic stewardship programs in developing countries such as Pakistan. Therefore, this study was designed to investigate the understanding of the fifth (final) year pharmacy students in seven universities in Pakistan about antibiotic use, antibiotic resistance, and antibiotic stewardship programs.

\section{Methodology}

\subsection{Study Setting}

This cross-sectional study was conducted in seven universities (three public and four private) in the Punjab province of Pakistan from October 2018 to January 2019. A selfadministered questionnaire was utilized for data collection among respondents. The eligibility criteria of this study included students who provided written informed consent, were willing to participate, and were enrolled in the final (fifth) year Pharm D. Students 
who were enrolled in other disciplines instead of pharmacy or junior Pharm D students were excluded.

\subsection{Questionnaire Development}

The questionnaire used for this survey was developed from a thorough literature survey [21-25]. The validity of the questionnaire was established by 2 professors of pharmacy background and 10 undergraduate pharmacy students. Minor changes to the final version of the questionnaire were made as per the recommendations of the experts.

There were seven sections of the questionnaire with 48-items (supplementary file). The demographic information such as age, gender, and type of university was obtained in the first section. In the second section, 14 questions were asked to determine pharmacy students' understanding of antibiotic use. The third section had questions related to antibiotic resistance and antibiotic stewardship programs. The fourth section focused on pharmacy students' understanding of the mechanism of antibiotic resistance with six questions. In the fifth section, information about factors affecting antibiotic resistance was recorded. Three options, such as "yes", "no", and "do not know", were provided as answer options from sections 1 to 6 . In the last section, the attitude of students about strategies to reduce antibiotic resistance was measured on a 5-point Likert scale measured from "strongly agree" to "strongly disagree." Each correct response in sections two to five was given one mark, and zero marks were given to each incorrect/do not know response. The overall score of each section was grouped into three main categories: poor (score 1-5 for antibiotic use section, score 1-3 for antibiotic resistance section, and 1-2 for the mode of $A B R$ and factors of $A B R$ section), average (score 6-10 for antibiotic use section, score 4-6 for antibiotic resistance section, 3-4 for the mode of ABR and factors of ABR section), and good (score $>10$ for antibiotic use section, score $>6$ for antibiotic resistance section, $>4$ for the mode of $A B R$ and factors of $A B R$ section).

A pilot study was executed with 20 final year pharmacy students. Cronbach-alpha test was used to determine the reliability and internal consistency of the questionnaire. The value of the reliability coefficient was 0.75 , which was in an acceptable range. The pilot sample was excluded in the final sample of the research.

\subsection{Sample Size}

The sample size $(n=227)$ was calculated using an online sample size software (Raosoft) with a $5 \%$ margin of error, $95 \%$ confidence interval, and $50 \%$ response distribution.

\subsection{Data Collection}

The data were collected by data collectors (undergraduate pharmacy students) trained by the study investigator about the study aims, questionnaire administration, and checking of the questionnaire's completeness. They approached a cohort of final year pharmacy students and distributed the questionnaire. It took 15-20 min to complete the survey. Any query raised by students was adequately addressed by the data collectors.

\subsection{Ethics Approval}

This study was conducted by following the Declaration of Helsinki. Participants were briefed about the objectives of the study, volunteer participation, and the right to withdraw. All participants provided informed consent prior to the study. Ethics approval was also obtained from Xi'an Jiaotong University (Ref: Phar-2018-015).

\subsection{Statistical Analysis}

Descriptive statistics were used to present data in percentages and frequencies. The normality of the data was assessed by Kolmogorov-Smirnov and Shapiro-Wilk tests. Median and interquartile ranges (IQRs) were measured as the data distribution was non-normal. Kruskal-Wallis and Mann-Whitney tests were computed on continuous data. Median antibiotic use score (measuring understanding about antibiotic use), median knowledge 
score (measuring knowledge about antibiotic resistance), median ABR mechanism score (measuring understanding about resistance mechanisms of antibiotics), median ABR factors score (measuring factors of antibiotic resistance), and median attitude score (measuring attitude towards approaches used to reduce antibiotic resistance) were also calculated and compared with demographics such as age, gender, and type of university. All data were analyzed using the Statistical Package for the Social Sciences (SPSS Inc, version 18, IBM, Chicago, IL, USA) with $p<0.05$ as statistically significant.

\section{Results}

\subsection{Demographics}

A total of 345 respondents were approached in seven universities of Punjab, Pakistan, and 296 respondents participated in this study with a response rate of $85.8 \%$. Most of the respondents were female $(n=184,62.2 \%)$ and had age in between $22-24$ years $(n=231$, $78.0 \%)$. The respondents' participation from public and private universities was the same (public $=148,50 \%$ vs. private $=148,50 \%)$ as indicated in Table 1 .

Table 1. Demographic characteristics of students $(n=296)$.

\begin{tabular}{|c|c|c|}
\hline Variable & Frequency $(n)$ & Percentage (\%) \\
\hline \multicolumn{3}{|l|}{ Gender } \\
\hline Male & 112 & 37.8 \\
\hline Female & 184 & 62.2 \\
\hline \multicolumn{3}{|l|}{ Age (years) } \\
\hline $19-21$ & 59 & 19.9 \\
\hline $22-24$ & 231 & 78.0 \\
\hline$>24$ & 6 & 2.0 \\
\hline \multicolumn{3}{|l|}{ Type of University } \\
\hline Public & 148 & 50.0 \\
\hline Private & 148 & 50.0 \\
\hline
\end{tabular}

\subsection{Understanding towards Antibiotic Use}

Overall, 177 (59.9\%) of the students fell into the average understanding category, whereas only $67(22.6 \%)$ respondents had a good understanding (Figure 1). Nevertheless, most of the respondents agreed that antibiotics are frequently prescribed antibacterials in both public $(n=261,88.2 \%)$ and private healthcare settings $(n=219,74.0 \%)$. They were aware that antibiotics should not be left over at home for future use $(n=211,71.3 \%)$, and patients should complete the antibiotic course even when symptoms get improved $(n=170,57.4 \%)$. The understanding of the respondents was limited in certain aspects of antibiotic use such as more than half of the respondents $(n=152,51.4 \%)$ said that antibiotics should be given as a preventive medication to tackle future infections, and $149(50.3 \%)$ respondents were unable to identify that diphenhydramine is not an antibiotic as shown in Table 2. The median antibiotic use score was significantly higher among respondents of public universities than private $($ Median $=1.5, \mathrm{IQR}=1.00$, vs. Median $=1.0, \mathrm{IQR}=0.88$; $p<0.001)$. 


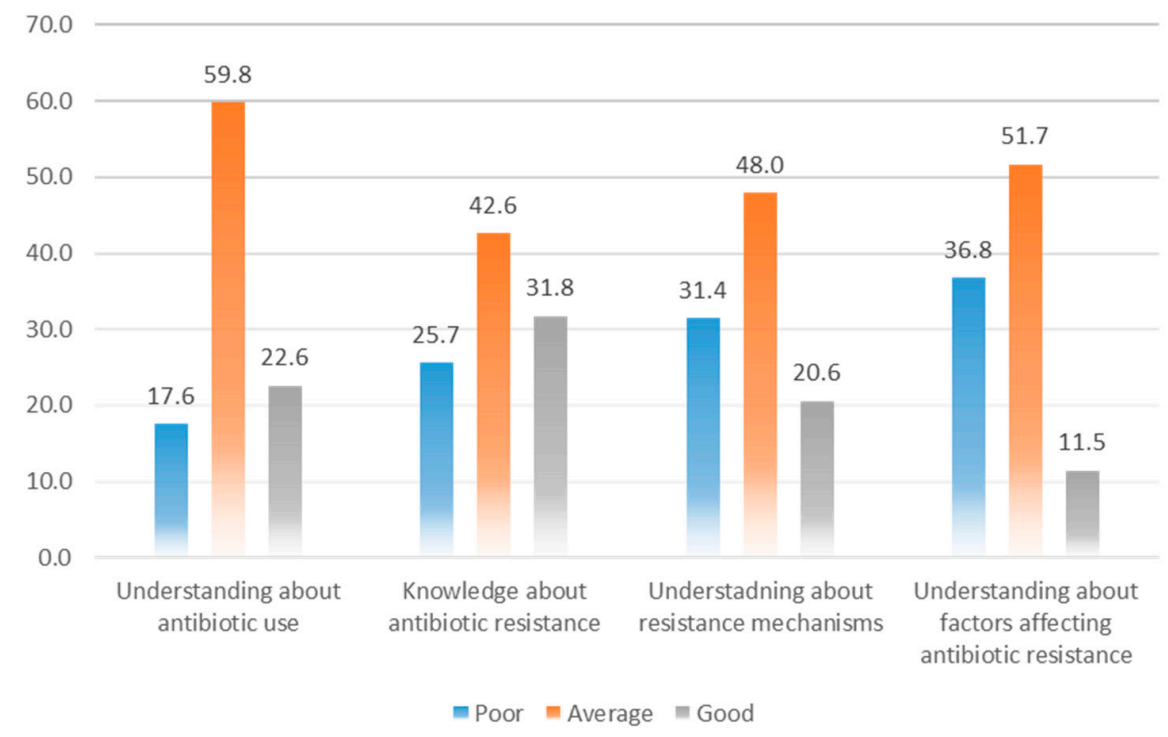

Figure 1. Understanding of respondents towards various aspects of antibiotic use and antibiotic resistance.

Table 2. Understanding about antibiotic use $n(\%)$.

\begin{tabular}{|c|c|c|c|c|c|}
\hline Questions & Yes & No & Do Not Know & Correct Rate & $\begin{array}{l}\text { Median } \\
\text { (IQR) }\end{array}$ \\
\hline $\begin{array}{l}\text { Antibiotics are the most commonly prescribed } \\
\text { anti-infective agents by public health-care } \\
\text { sector facilities }\end{array}$ & $261(88.2)$ & $30(10.1)$ & $5(1.7)$ & $261(88.2)$ & $1(0)$ \\
\hline $\begin{array}{l}\text { Antibiotics are the most commonly prescribed } \\
\text { anti-infective agents by private health-care } \\
\text { sector facilities }\end{array}$ & $219(74.0)$ & $67(22.6)$ & $10(3.4)$ & $219(74.0)$ & $1(1)$ \\
\hline $\begin{array}{l}\text { Common cold if treated with antibiotics will make the } \\
\text { patients recover more quickly }\end{array}$ & $129(43.6)$ & $130(43.9)$ & $37(12.5)$ & $130(43.9)$ & $2(1)$ \\
\hline $\begin{array}{l}\text { Antibiotics should be prescribed as preventive measures } \\
\text { to fight against future microbial attacks }\end{array}$ & $152(51.4)$ & $124(41.9)$ & $20(6.8)$ & $124(41.9)$ & $1(1)$ \\
\hline Antibiotics cannot treat influenza & $134(45.3)$ & $138(46.6)$ & $24(8.1)$ & $134(45.3)$ & $2(1)$ \\
\hline Antibiotics are indicated to relieve pain & $100(33.8)$ & $164(55.4)$ & $32(10.8)$ & $164(55.4)$ & $2(1)$ \\
\hline $\begin{array}{l}\text { Antibiotics might develop allergy in } \\
\text { susceptible individuals }\end{array}$ & $215(72.6)$ & $58(19.6)$ & $23(7.8)$ & $215(72.6)$ & $1(1)$ \\
\hline $\begin{array}{l}\text { Diphenhydramine is an antibiotic used in treating upper } \\
\text { respiratory infections }\end{array}$ & $149(50.3)$ & $117(39.5)$ & $30(10.1)$ & $117(39.5)$ & $1(1)$ \\
\hline $\begin{array}{l}\text { Cefotaxime belongs to the } \\
\text { third-generation cephalosporins }\end{array}$ & $179(60.5)$ & $69(23.3)$ & $48(16.2)$ & $179(60.5)$ & $1(1)$ \\
\hline $\begin{array}{c}\text { Patients can stop taking antibiotics when the symptoms } \\
\text { are improving }\end{array}$ & $98(33.1)$ & $161(54.4)$ & $37(12.5)$ & $161(54.4)$ & $2(1)$ \\
\hline $\begin{array}{l}\text { Keeping the left-over antibiotic course for the next time } \\
\text { treatment of the same type of infection is a good practice }\end{array}$ & $68(23.0)$ & $211(71.3)$ & $17(5.7)$ & $211(71.3)$ & $2(0)$ \\
\hline $\begin{array}{l}\text { Antibiotics treatment can eliminate most of the sensitive } \\
\text { bacterial cells from patients }\end{array}$ & $170(57.4)$ & $100(33.8)$ & $26(8.8)$ & $170(57.4)$ & $1(1)$ \\
\hline $\begin{array}{c}\text { Antibiotics can be obtained without a prescription } \\
\text { in Pakistan }\end{array}$ & $221(74.7)$ & $63(21.3)$ & $12(4.1)$ & $221(74.7)$ & $1(1)$ \\
\hline Antibiotics are the first line of treatment in sore throat & $123(41.6)$ & $132(44.6)$ & $41(13.9)$ & $132(44.6)$ & $2(1)$ \\
\hline
\end{tabular}




\subsection{Understanding of Antibiotic Resistance}

The majority of the students $(n=237,80.1 \%)$ were aware of the term "antibiotic resistance" as this was taught to them during their Pharm D $(n=195,65.9 \%)$. However, the respondents were not familiar with the term "antibiotic stewardship program" ( $n=192$, $64.9 \%)$, and 177 (59.8\%) respondents said that they had not been taught about antibiotic stewardship (Figure 2).

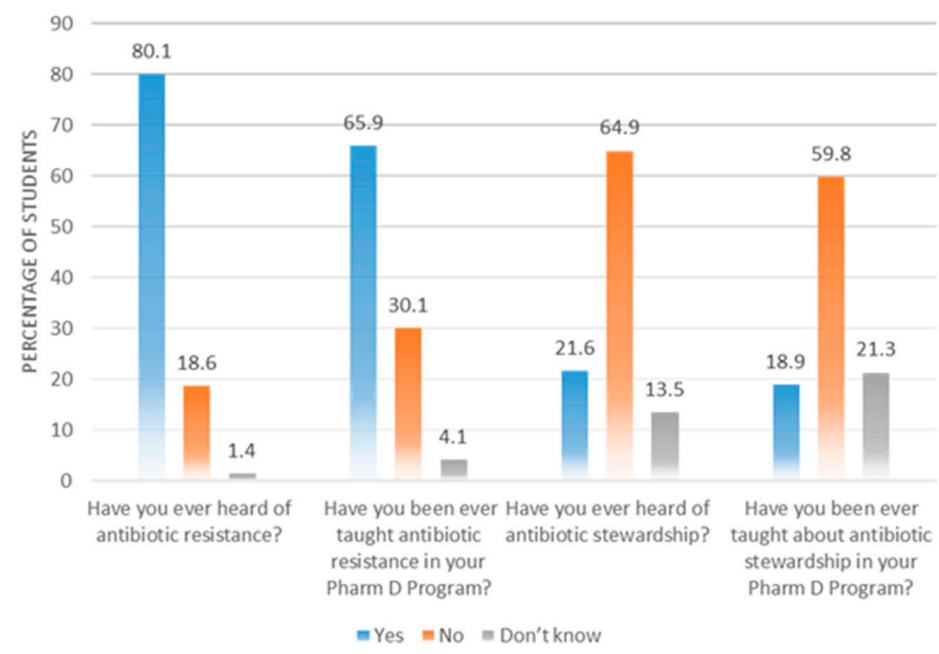

Figure 2. Awareness of students about antibiotic resistance and stewardship.

A large number of respondents $(n=126,42.6 \%)$ had an average level of ABR related knowledge, whereas only $94(31.8 \%)$ had good knowledge (Figure 1$)$. The respondents rightly said that inadequate therapy $(n=189,63.9 \%)$ and doses could lead to ABR $(n=222$, $75.0 \%)$. Likewise, $160(54.1 \%)$ respondents were aware that healthcare professionals could transfer-resistant strains from an infected patient to a healthy person. A detailed understanding of ABR is listed in Table 3.

Table 3. Understanding about antibiotic resistance use $n(\%)$.

\begin{tabular}{|c|c|c|c|c|c|}
\hline Questions & Yes & No & Do Not Know & Correct Rate & $\underset{\text { (IQR) }}{\text { Median }}$ \\
\hline $\begin{array}{l}\text { A resistant bacterium cannot spread in } \\
\text { healthcare institutions }\end{array}$ & $121(40.9)$ & $168(56.8)$ & $7(2.4)$ & $168(56.8)$ & $2(1)$ \\
\hline $\begin{array}{l}\text { Health care workers serve as vectors carrying resistant } \\
\text { strains from infected patients to normal patients }\end{array}$ & $160(54.1)$ & $120(40.5)$ & $16(5.4)$ & $160(54.1)$ & $1(1)$ \\
\hline $\begin{array}{l}\text { Exposure to antibiotics appears to be the principal risk } \\
\text { factor for the emergence of antibiotic-resistant bacteria }\end{array}$ & 215 (72.6) & 59 (19.9) & $22(7.4)$ & 215 (72.6) & $1(1)$ \\
\hline $\begin{array}{l}\text { Inadequate duration of therapy contributes to antibiotic } \\
\text { resistance leading to poor patient compliance }\end{array}$ & $189(63.9)$ & $90(30.4)$ & $17(5.7)$ & $189(63.9)$ & $1(1)$ \\
\hline $\begin{array}{l}\text { Inadequate doses contribute to antibiotic resistance due } \\
\text { to poorly designed dosing regimen }\end{array}$ & $222(75.0)$ & 57 (19.3) & $17(5.7)$ & $222(75.0)$ & $1(0.75)$ \\
\hline $\begin{array}{c}\text { Antimicrobial resistance can be minimized through } \\
\text { changing empiric therapy to a selected narrow-spectrum } \\
\text { therapy in response to the availability of culture and } \\
\text { sensitivity results }\end{array}$ & $219(74.0)$ & $60(20.3)$ & $17(5.7)$ & $219(74.0)$ & $1(1)$ \\
\hline $\begin{array}{c}\text { Cross-resistance is the condition in which resistance } \\
\text { occurs to a particular antibiotic that often results in } \\
\text { resistance to other antibiotics, usually from a } \\
\text { similar class }\end{array}$ & $185(62.5)$ & $83(28.0)$ & $28(9.5)$ & $185(62.5)$ & $1(1)$ \\
\hline $\begin{array}{c}\text { Lack of enforcement regulation sometimes permits } \\
\text { antibiotics to be purchased without a prescription } \\
\text { from pharmacies }\end{array}$ & $206(69.6)$ & $80(27.0)$ & $10(3.4)$ & $206(69.6)$ & $1(1)$ \\
\hline
\end{tabular}


The respondents aged 19-21 years had significantly higher understanding of ABR compared to those with age $>24$ years (Median $=1.5, \mathrm{IQR}=1.00$, vs. Median $=1.0$, $\mathrm{IQR}=1.00 ; p<0.001)$. Similarly, the median score of respondents of public universities was noted to be higher than respondents of private universities (Median $=1.5, \mathrm{IQR}=1.00$, vs Median $=1.0, \mathrm{IQR}=0.00 ; p<0.001)$ as indicated in Table 7.

\subsection{Understanding of the Mode of Action of Antibiotics}

The understanding of most of the respondents $(n=142,48 \%)$ about the resistance mechanism was average; however, 61 (20.6\%) had a good understanding (Figure 1). Many students agreed that beta-lactamases cause the breakdown of beta-lactam antibiotics $(n=213$, $72.0 \%)$, and bacteria could use drug efflux mechanisms to produce ABR $(n=164,55.4 \%)$ as shown in Table 4. However, a minimal number of respondents answered correctly about statements such as "There is no resistance to penicillin for Streptococcus pyogenes" ( $n=90$, $30.4 \%)$. The respondents with age 19-21 years were more aware of the ABR mechanisms than 22-24 years (Median $=2.0, \mathrm{IQR}=0.50$, Median $=1.5, \mathrm{IQR}=1.00 ; p=0.002)$ (Table 7).

Table 4. Understanding of respondents about the resistance mechanisms of antibiotics $n(\%)$.

\begin{tabular}{|c|c|c|c|c|c|}
\hline Questions & Yes & No & Do Not Know & Correct Rate & $\begin{array}{l}\text { Median } \\
\text { (IQR) }\end{array}$ \\
\hline $\begin{array}{l}\text { Beta-lactamase is an enzyme produced by bacteria that } \\
\text { breakdown the beta-lactam antibiotics }\end{array}$ & $213(72.0)$ & $72(24.3)$ & $11(3.7)$ & $213(72.0)$ & $1(1)$ \\
\hline $\begin{array}{l}\text { Bacteria acquire efflux pumps that extrude the } \\
\text { antibacterial agent from the cell before it can reach its } \\
\text { target site and exert its effect }\end{array}$ & $164(55.4)$ & $67(22.6)$ & $65(22.0)$ & $164(55.4)$ & $1(1)$ \\
\hline $\begin{array}{l}\text { There is no resistance to penicillin for } \\
\text { Streptococcus pyogenes bacteria }\end{array}$ & $90(30.4)$ & $113(38.2)$ & $93(31.4)$ & $90(30.4)$ & $2(2)$ \\
\hline $\begin{array}{l}\text { Bacteriostatic antibiotics are the same as } \\
\text { bactericidal antibiotics }\end{array}$ & $48(16.2)$ & $191(64.5)$ & $57(19.3)$ & $191(64.5)$ & $2(0)$ \\
\hline $\begin{array}{l}\text { Antibiotic refers to any agent used to kill or inhibit the } \\
\text { growth of microorganisms }\end{array}$ & $180(60.8)$ & $70(23.6)$ & $46(15.5)$ & $180(60.8)$ & $1(1)$ \\
\hline Enterococcus is a vancomycin-resistant bacterium & $115(38.9)$ & $79(26.7)$ & $102(34.5)$ & $115(38.9)$ & $2(2)$ \\
\hline
\end{tabular}

\subsection{Understanding of the Factors of Antibiotic Resistance}

More than half of the respondents $(n=153,51.7 \%)$ had an average understanding of ABR factors (Figure 1). The respondents knew that mutation is a contributing factor leading to protein change in bacteria $(n=188,63.5 \%)$, and broad-spectrum antibiotics used as first-line therapy for minor infections could amplify ABR risk $(n=189,63.9 \%)$. A total of 194 (65.5\%) respondents believed that healthcare-associated infections contribute to ABR. Alternatively, 87 (29.4) agreed that commercially available biocide antiseptics in soaps are not useful for patients with skin infections (Table 5). The understanding of students from public universities was found to be significantly higher about the factors of ABR compared to private university students $($ Median $=1.0, \mathrm{IQR}=1.00$ vs. Median $=1.0, \mathrm{IQR}=0.00$; $p<0.001)$. 
Table 5. Understanding about factors contributing to antibiotic use $n(\%)$.

\begin{tabular}{|c|c|c|c|c|c|}
\hline Questions & Yes & No & Do Not Know & Correct Rate & $\begin{array}{l}\text { Median } \\
\text { (IQR) }\end{array}$ \\
\hline $\begin{array}{c}\text { The mutation is a prevalence factor in changing the } \\
\text { bacterial protein, which is often the target of } \\
\text { antibiotic treatment }\end{array}$ & $188(63.5)$ & $61(20.6)$ & 47 (15.9) & $188(63.5)$ & $1(1)$ \\
\hline $\begin{array}{l}\text { The use of broad-spectrum antibiotics } \\
\text { (e.g., 4th generation cephalosporins) as initial therapy } \\
\text { for mild infection may increase the risk of } \\
\text { antibiotic resistance }\end{array}$ & $189(63.9)$ & $83(28.0)$ & $24(8.1)$ & 189 (63.9) & $1(1)$ \\
\hline $\begin{array}{l}\text { The use of commercially available biocide antiseptics in } \\
\text { soaps is highly recommended to patients who have } \\
\text { skin infections }\end{array}$ & $182(61.5)$ & 87 (29.4) & $27(9.1)$ & $87(29.4)$ & $1(1)$ \\
\hline $\begin{array}{l}\text { Antibiotic resistance tends to be a feature of urban } \\
\text { social change }\end{array}$ & $199(67.2)$ & 58 (19.6) & 39 (13.2) & $199(67.2)$ & $1(1)$ \\
\hline $\begin{array}{l}\text { Healthcare acquired infections are a breeding ground } \\
\text { for antimicrobial resistance }\end{array}$ & $194(65.5)$ & $65(22.0)$ & 37 (12.5) & $194(65.5)$ & $1(1)$ \\
\hline
\end{tabular}

\subsection{Attitude toward Reducing Antibiotic Resistance}

The attitude of a large number of respondents was positive towards reducing the $\mathrm{ABR}$ burden. More than half of the respondents strongly agreed that educating healthcare professionals $(n=158,53.4 \%)$ and medical students about the prescribing and usage of antibiotics could reduce the ABR burden ( $n=150,50.7 \%)$. A total of $171(57.8 \%)$ respondents perceived that the rational use of antibiotics could reduce the hospital's expense. Likewise, $155(52.4 \%)$ said that antibiotic prescribing via phone is not suitable for patients. Most of the respondents agreed that patients should be advised to participate in antibiotic awareness campaigns to enhance their knowledge. $123(41.6 \%)$ of the respondents believed that pharmacists should dispense antibiotics according to the demand of patients (Table 6). The median attitude score of respondents was also significantly associated with gender, age, and university type (Table 7).

Table 6. Attitude towards minimizing antibiotic resistance $n(\%)$.

\begin{tabular}{|c|c|c|c|c|c|c|}
\hline Questions & Strongly Agree & Agree & Neutral & Disagree & Strongly Disagree & Median (IQR) \\
\hline $\begin{array}{l}\text { Educating healthcare } \\
\text { professional in terms of } \\
\text { appropriate } \\
\text { antibiotic prescribing }\end{array}$ & $158(53.4)$ & $99(33.4)$ & $31(10.5)$ & $4(1.4)$ & $4(1.4)$ & $1(1)$ \\
\hline $\begin{array}{l}\text { Formal teaching on the proper } \\
\text { usage of antimicrobial agents } \\
\text { among health care students } \\
\text { may minimize the phenomenon } \\
\text { of antibiotic resistance }\end{array}$ & $150(50.7)$ & $101(34.1)$ & $27(9.1)$ & $17(5.7)$ & $1(0.3)$ & $1(1)$ \\
\hline $\begin{array}{l}\text { Antimicrobial education is } \\
\text { needed to be well received by } \\
\text { healthcare practitioners }\end{array}$ & $164(55.4)$ & $91(30.7)$ & $23(7.8)$ & $12(4.1)$ & $6(2.0)$ & $1(1)$ \\
\hline $\begin{array}{c}\text { The usage of antibiotics must } \\
\text { be related to specialities to } \\
\text { enhance the awareness of } \\
\text { antibiotic resistance }\end{array}$ & $126(42.6)$ & $132(44.6)$ & $17(5.7)$ & $13(4.4)$ & $8(2.7)$ & $2(1)$ \\
\hline
\end{tabular}


Table 6. Cont.

\begin{tabular}{|c|c|c|c|c|c|c|}
\hline Questions & Strongly Agree & Agree & Neutral & Disagree & Strongly Disagree & Median (IQR) \\
\hline $\begin{array}{l}\text { Appropriate use of the } \\
\text { antibiotic may not have any } \\
\text { impact on the hospital's total } \\
\text { cost expenses on medications }\end{array}$ & $18(6.1)$ & $0(0.0)$ & 49 (16.6) & $171(57.8)$ & $58(19.6)$ & $4(0)$ \\
\hline $\begin{array}{l}\text { Prescribing antibiotics over the } \\
\text { phone is a good patient care }\end{array}$ & $67(22.6)$ & $0(0.0)$ & $58(19.6)$ & $155(52.4)$ & $16(5.4)$ & $4(1)$ \\
\hline $\begin{array}{l}\text { The patient should be advised } \\
\text { to keep part of the antibiotic } \\
\text { course for another occasion } \\
\text { which will help them in cutting } \\
\text { down the medical cost }\end{array}$ & $21(7.1)$ & $116(39.2)$ & $56(18.9)$ & $60(20.3)$ & $43(14.5)$ & $3(2)$ \\
\hline $\begin{array}{l}\text { Pharmacists should be } \\
\text { encouraged to dispense } \\
\text { antibiotics to meet the } \\
\text { patients demands }\end{array}$ & $81(27.4)$ & $123(41.6)$ & $41(13.9)$ & $25(8.4)$ & $26(8.8)$ & $6(4)$ \\
\hline
\end{tabular}

Table 7. Association of median scores with demographic variables.

\begin{tabular}{|c|c|c|c|c|c|c|c|c|c|c|}
\hline Variable & $\begin{array}{l}\text { Median } \\
\text { ABU } \\
\text { Score } \\
\text { (IQR) }\end{array}$ & $p$-Value & $\begin{array}{c}\text { Median } \\
\text { Knowledge } \\
\text { Score (IQR) }\end{array}$ & $p$-Value & $\begin{array}{c}\text { Median } \\
\text { ABR } \\
\text { Mechanism } \\
\text { Score (IQR) }\end{array}$ & $p$-Value & $\begin{array}{c}\text { Median } \\
\text { FAR } \\
\text { Score } \\
\text { (IQR) }\end{array}$ & $p$-Value & $\begin{array}{c}\text { Median } \\
\text { Attitude } \\
\text { Score } \\
\text { (IQR) }\end{array}$ & $p$-Value \\
\hline \multicolumn{11}{|l|}{ Gender* } \\
\hline $\begin{array}{c}\text { Male } \\
\text { Female }\end{array}$ & $\begin{array}{l}1.5(1.00) \\
1.0(1.00)\end{array}$ & 0.235 & $\begin{array}{l}1.0(0.88) \\
1.0(0.50)\end{array}$ & 0.491 & $\begin{array}{l}1.5(0.50) \\
1.5(0.50)\end{array}$ & 0.116 & $\begin{array}{l}1.0(1.00) \\
1.0(1.00)\end{array}$ & 0.527 & $\begin{array}{l}2.0(0.50) \\
2.0(0.50)\end{array}$ & 0.010 \\
\hline \multicolumn{11}{|c|}{ Age (years) $* *$} \\
\hline $\begin{array}{c}19-21 \\
22 \text { to } 24 \\
>24\end{array}$ & $\begin{array}{l}1.5(1.00) \\
1.0(1.00) \\
1.0(1.00)\end{array}$ & 0.128 & $\begin{array}{l}1.5(1.00) \\
1.0(0.50) \\
1.0(1.00)\end{array}$ & 0.001 & $\begin{array}{l}2.0(0.50) \\
1.5(1.00) \\
2.0(0.75)\end{array}$ & 0.002 & $\begin{array}{l}1.0(1.00) \\
1.0(1.00) \\
1.0(1.25)\end{array}$ & 0.798 & $\begin{array}{l}2.0(1.00) \\
2.0(1.00) \\
2.0(0.50)\end{array}$ & 0.043 \\
\hline \multicolumn{11}{|c|}{ University type * } \\
\hline $\begin{array}{l}\text { Public } \\
\text { Private }\end{array}$ & $\begin{array}{l}1.5(1.00) \\
1.0(0.88)\end{array}$ & $<0.001$ & $\begin{array}{l}1.5(1.00) \\
1.0(0.00)\end{array}$ & $<0.001$ & $\begin{array}{l}1.5(1.00) \\
1.5(1.00)\end{array}$ & 0.143 & $\begin{array}{l}1.0(1.00) \\
1.0(0.00)\end{array}$ & $<0.001$ & $\begin{array}{l}2.0(1.50) \\
2.0(0.50)\end{array}$ & 0.002 \\
\hline
\end{tabular}

* Mann-Whitney test, ${ }^{* *}$ Kruskal-Wallis test, $\mathrm{ABU}=$ antibiotic use, ABR = antibiotic resistance, FAR = factors affecting antibiotic resistance.

\section{Discussion}

This is the first comprehensive study that illustrates the understanding of final-year pharmacy students from 7 Pakistani universities about antibiotic use, ABR, and antibiotics stewardship programs. The findings of this study show that students have an average understanding of certain aspects of antibiotic use and $A B R$, and their attitude is positive towards the approaches used to limit progression in ABR.

Most of the respondents of our study believed that antibiotics are widely used antimicrobials in public and private hospitals. Similar results were reported in a Malaysian study [21]. Additionally, a recent study described that half of the antibiotics used in hospitalized patients are inappropriate [26].

Nearly half of our survey respondents (46.6\%) agreed that influenza could be treated with antibiotics. The current research is in concordance with a study conducted in SaudiArabia, which reported that more than one-fourth of respondents (medical students) wrongly perceived that antibiotics are useful against viral infections [27]. Unfortunately, the use of antibiotics in viral diseases such as influenza is widespread in the community and hospitals [28], which could be due to a lack of optimum antibiotic-related knowledge among healthcare workers and the public $[29,30]$.

A total of $74.7 \%$ of the respondents said that antibiotic dispensing does not require a prescription in Pakistan. According to the Drug Act 1967 of Pakistan, dispensing antibiotics without a valid prescription is prohibited; however, the irrational dispensing of antibiotics 
is widespread [6,31]. Many studies from Pakistan have reported that pharmacists and pharmacy technicians routinely dispense antibiotics without inquiring about a prescription [32-34]. The respondents of our study righty pointed out that non-compliance to regulations often permits the purchase of antibiotics without a prescription from community pharmacies. The government should take strict measures against irrational antibiotic dispensing, and appropriate punishments should be given for non-compliance with regulations. Besides, the government should advise community pharmacies and other drug outlets to maintain a record of the sale of antibiotics coupled with photocopies of the prescriptions.

More than half of the survey respondents agreed that healthcare workers could act as a vector to transfer resistant strains of pathogens within a hospital. This complies with various studies [35,36], such as a study conducted in Tanzania that found that healthcare workers, including nurses, had a high percentage of MRSA carriage [37]. Like a previous study [21], many respondents believed that switching empiric therapy to definitive therapy in the presence of culture and sensitivity tests could help reduce ABR. Nearly two-thirds of the respondents understood that inadequate antibiotic therapy duration could lead to ABR, as found in a study conducted in Malaysian pharmacy students [21]. It is recommended that antibiotics should be used for an optimal duration as recommended by healthcare professionals, and their inappropriate use could potentiate the risk of ABR [38,39].

Only $30.4 \%$ of our study respondents correctly answered that there is no resistance of Streptococcus pyogenes against penicillin. However, this percentage is still higher than a study conducted on physicians, where only $21 \%$ of physicians were able to show this knowledge [40]. On the other hand, this correctness is far less than a Malaysian study (56.6\%) [21].

Most of our study respondents were familiar with ABR as this was taught to them during their PharmD; however, their awareness towards antibiotic stewardship programs was limited. Our previous study conducted with clinicians also showed limited awareness of stewardship programs [41]. Although ABR is now a part of the curriculum in many pharmacy schools, information about stewardship programs is still missing. Many countries, such as South Africa and the United States, have successfully included antibiotic stewardship programs in their pharmacy curricula [42,43].

Surprisingly, $61.5 \%$ of students advocated using soaps containing biocide antiseptics for patients with cutaneous infections. This percentage is far more than a previous study [21]. This wrong perception among students might come from the fact that antibiotic creams are often prescribed to treat skin infections.

A large number of students were in agreement that healthcare professionals and medical students should have adequate education and training regarding optimum antibiotic prescribing and ABR. Many previous studies have highlighted the importance of education and training of healthcare professionals and students [44,45]. Besides, studies have shown the positive impact of education on antibiotic prescribing practices of healthcare professionals [46]. A considerable number of students thought that antibiotics should be provided to meet the demands of patients. This negative attitude may be due to the self-medication trend among medical students. This belief can be further motivated by the urge to get prompt relief from illness and avoid clinician fees.

In this study, the understanding of public sector university students about various $A B R$ aspects was significantly higher than that of private universities. This may be because pharmacy institutes in public universities of Pakistan are equipped with an adequate number of trained and experienced academic staff coupled with sufficient laboratory facilities.

A better theoretical understanding of antibiotics is integral for a better practical attitude of pharmacy students. There is a need to revise and continuously update the Pharm D curriculum by adding comprehensive information about antibiotic resistance and antibiotic stewardship programs $[47,48]$. In addition, the pharmacy students should be provided with an opportunity to participate in hospital ward rounds to better understand the concept of ABR. Furthermore, the government should implement antibiotic stewardship 
in all health care settings of Pakistan to provide a discussion forum for medical doctors and pharmacy students to get solutions to ABR based on evidence $[6,33,49]$.

The authors acknowledge certain limitations within this study. First, this study was conducted in selected universities, opting for a convenience sampling technique, which may cause selection bias. Second, the study was undertaken in only one province of Pakistan, and therefore, the results are unable to offer generalizability. Nevertheless, this is an exploratory study that provides the latest insight of final-year pharmacy students about $\mathrm{ABR}$ and antibiotic stewardship programs.

\section{Conclusions}

This study undertaken with final-year pharmacy students from Pakistani universities has highlighted gaps in understanding the main aspects of antibiotic use, ABR, and stewardship programs. However, students showed positive attitudes towards different approaches used to manage ABR in Pakistan. A significant association between the type of university with antibiotic use, $A B R$, factors of $A B R$ and attitude towards $A B R$ eradication were noted. Interventions such as revising the pharmacy curricula by incorporating courses related to ABR and stewardship, coupled with adequate problem-based practical training of pharmacy students are recommended. Future studies covering a larger proportion of pharmacy students across the country are needed to confirm the findings of this study.

Supplementary Materials: The following are available online at https:/ / www.mdpi.com/2079-638 2/10/1/66/s1, Questionnaire: Understanding of pharmacy students towards antibiotic use, antibiotic resistance and antibiotic stewardship programs: a cross-sectional study from Punjab, Pakistan.

Author Contributions: Conceptualization, K.H., S.J., N.U.H., J.C., and Y.F.; formal analysis, K.H.; funding acquisition, Y.F.; methodology, K.H., J.C., and U.R.M.; project administration, M.F.R., U.R.M., A.U.R., and K.M.K.; supervision, Y.F.; writing—original draft, K.H.; writing—review and editing, S.J., M.R., N.U.H., and Y.F. All authors have read and agreed to the published version of the manuscript.

Funding: This work was funded by the "Young Talent Support Plan" and "High Achiever Plan" of the Health Science Center, Xi'an Jiaotong University, and the Central University Basic Research Fund (2015qngz05).

Institutional Review Board Statement: The study was conducted according to the guidelines of the Declaration of Helsinki, and approved by the Ethics Committee of Xi'an Jiaotong University (Ref: Phar-2018-015).

Informed Consent Statement: Informed consent was obtained from all subjects involved in the study.

Data Availability Statement: The dataset used in this study is available from the corresponding author upon reasonable request.

Acknowledgments: The authors would like to thank all participants of this study.

Conflicts of Interest: The authors declare no conflict of interest.

\section{References}

1. Martin, J.K.; Sheehan, J.P.; Bratton, B.P.; Moore, G.M.; Mateus, A.; Li, S.H.-J.; Kim, H.; Rabinowitz, J.D.; Typas, A.; Savitski, M.M.; et al. A Dual-Mechanism Antibiotic Kills Gram-Negative Bacteria and Avoids Drug Resistance. Cell 2020, 181, 1518-1532.e14. [CrossRef] [PubMed]

2. Implementation of the Global Action Plan on AMR. WHO GAP AMR Newletter No. 24. Available online: https://www.who.int/ antimicrobial-resistance/news/who-gap-amr-newsletter-march-2017.pdf (accessed on 10 December 2020).

3. US Department of Health and Human Services. Antibiotic Resistance Threats in the United States, Centers for disease control and prevention. Available online: https:/ /www.cdc.gov/drugresistance/pdf/ar-threats-2013-508.pdf (accessed on 10 December 2020).

4. ECDC/EMEA Joint Technical Report. The Bacterial Challenge: Time to React-A Call to Narrow the Gap between Multidrugresistant Bacteria in the EU and the Development of New Antibacterial Agents. European Centre for Disease Prevention and Control \& European Medicines Agency. Available online: https:/ /ecdc.europa.eu/sites/portal/files/media/en/publications/ Publications/0909_TER_The_Bacterial_Challenge_Time_to_React.pdf (accessed on 10 December 2020). 
5. Auta, A.; Hadi, M.A.; Oga, E.; Adewuyi, E.O.; Abdu-Aguye, S.N.; Adeloye, D.; Strickland-Hodge, B.; Morgan, D.J. Global access to antibiotics without prescription in community pharmacies: A systematic review and meta-analysis. J. Infect. 2019, 78, 8-18. [CrossRef] [PubMed]

6. Hayat, K.; Rosenthal, M.M.; Gillani, A.H.; Zhai, P.; Aziz, M.M.; Li, J.; Chang, J.; Hu, H.; Fang, Y. Perspective of Pakistani Physicians towards Hospital Antimicrobial Stewardship Programs: A Multisite Exploratory Qualitative Study. Int. J. Environ. Res. Public Health 2019, 16, 1565. [CrossRef] [PubMed]

7. Hayat, K.; Li, P.; Rosenthal, M.; Xu, S.; Chang, J.; Gillani, A.H.; Khan, F.U.; Sarwar, M.R.; Ji, S.; Shi, L.; et al. Perspective of community pharmacists about community-based antimicrobial stewardship programs. A multicenter cross-sectional study from China. Expert Rev. Anti-Infect. Ther. 2019, 17, 1043-1050. [CrossRef] [PubMed]

8. Chaintarli, K.; Ingle, S.M.; Bhattacharya, A.; Ashiru-Oredope, D.; Oliver, I.; Gobin, M. Impact of a United Kingdom-wide campaign to tackle antimicrobial resistance on self-reported knowledge and behaviour change. BMC Public Health 2016, 16, 393. [CrossRef] [PubMed]

9. Lim, J.M.; Singh, S.R.; Duong, M.C.; Legido-Quigley, H.; Hsu, L.Y.; Tam, C. Impact of national interventions to promote responsible antibiotic use: A systematic review. J. Antimicrob. Chemother. 2020, 75, 14-29. [CrossRef] [PubMed]

10. World Health Organization. Global Action Plan on Antimicrobial Resistance. Available online: http://www.wpro.who.int/ entity/drug_resistance/resources/global_action_plan_eng.pdf (accessed on 10 December 2020).

11. Justo, J.A.; Gauthier, T.P.; Scheetz, M.H.; Chahine, E.B.; Bookstaver, P.B.; Gallagher, J.C.; Hermsen, E.D.; DePestel, D.D.; Ernst, E.J.; Jacobs, D.M.; et al. Knowledge and Attitudes of Doctor of Pharmacy Students Regarding the Appropriate Use of Antimicrobials. Clin. Infect. Dis. 2014, 59, S162-S169. [CrossRef]

12. Fay, L.N.; Wolf, L.M.; Brandt, K.L.; Deyoung, G.R.; Anderson, A.M.; Egwuatu, N.E.; Dumkow, L.E. Pharmacist-led antimicrobial stewardship program in an urgent care setting. Am. J. Health Pharm. 2019, 76, 175-181. [CrossRef]

13. Westerhof, L.R.; Dumkow, L.E.; Hanrahan, T.L.; McPharlin, S.V.; Egwuatu, N.E. Outcomes of an ambulatory care pharmacist-led antimicrobial stewardship program within a family medicine resident clinic. Infect. Control. Hosp. Epidemiol. 2020, 1-7. [CrossRef]

14. Gebretekle, G.B.; Mariam, D.H.; Taye, W.A.; Fentie, A.M.; Degu, W.A.; Alemayehu, T.; Beyene, T.; Libman, M.; Fenta, T.G.; Yansouni, C.P.; et al. Half of Prescribed Antibiotics Are Not Needed: A Pharmacist-Led Antimicrobial Stewardship Intervention and Clinical Outcomes in a Referral Hospital in Ethiopia. Front. Public Health 2020, 8, 109. [CrossRef]

15. Deshpande, P.R.; Vantipalli, R.; Lakshmi, C.H.C.; Rao, E.J.; Regmi, B.; Ahad, A.; Nirojini, P.S. Clinical pharmacists: The major support to Indian healthcare system in near future. J. Pharm. Bioallied Sci. 2015, 7, 161-174. [CrossRef]

16. Bhagavathula, A.S.; Sarkar, B.R.; Patel, I. Clinical pharmacy practice in developing countries: Focus on India and Pakistan. Arch. Pharm. Pr. 2014, 5, 91. [CrossRef]

17. Shi, L.; Chang, J.; Liu, X.; Zhai, P.; Hu, S.; Li, P.; Hayat, K.; Kabba, J.A.; Feng, Z.; Yang, C.; et al. Dispensing Antibiotics without a Prescription for Acute Cough Associated with Common Cold at Community Pharmacies in Shenyang, Northeastern China: A Cross-Sectional Study. Antibiotics 2020, 9, 163. [CrossRef] [PubMed]

18. Ashraf, M.S.; Chung, P.; Neukirch, A.; Bergman, S.; Cavalieri, R.J.; Ortmeier, R.; Rupp, M.; Wichman, C.; Van Schooneveld, T.C. Impact of Training Consultant Pharmacists on Antimicrobial Stewardship Programs in Long-Term Care Facilities. Infect. Control. Hosp. Epidemiol. 2020, 41, s446-s448. [CrossRef]

19. The Drug Act. Available online: http:/ / punjablaws.gov.pk/laws/1458a.html (accessed on 12 December 2020).

20. Pharmacy Council of Pakistan. Available online: https://www.pharmacycouncil.org.pk/ (accessed on 12 December 2020).

21. Rajiah, K.; Ren, W.S.; Jamshed, S.Q. Evaluation of the understanding of antibiotic resistance among Malaysian pharmacy students at public universities: An exploratory study. J. Infect. Public Health 2015, 8, 266-273. [CrossRef]

22. Inácio, J.; Barnes, L.-M.; Jeffs, S.; Castanheira, P.S.P.; Wiseman, M.; Inácio, S.; Bowler, L.; Lansley, A. Master of Pharmacy students' knowledge and awareness of antibiotic use, resistance and stewardship. Curr. Pharm. Teach. Learn. 2017, 9, 551-559. [CrossRef]

23. Zhou, X.D.; Wang, X.; Tucker, J.D.; Little, P.; Moore, M.; Fukuda, K.; Zhou, X.D. Knowledge, Attitude, and Practice with Respect to Antibiotic Use among Chinese Medical Students: A Multicentre Cross-Sectional Study. Int. J. Environ. Res. Public Health 2018, 15, 1165. [CrossRef]

24. Sakeena, M.H.F.; Bennett, A.A.; Jamshed, S.Q.; Mohamed, F.; Herath, D.R.; Gawarammana, I.; McLachlan, A.J. Investigating knowledge regarding antibiotics and antimicrobial resistance among pharmacy students in Sri Lankan universities. BMC Infect. Dis. 2018, 18, 209. [CrossRef]

25. Burger, M.; Fourie, J.; Loots, D.; Mnisi, T.; Schellack, N.; Bezuidenhout, S.; Meyer, J.C. Knowledge and perceptions of antimicrobial stewardship concepts among final year pharmacy students in pharmacy schools across South Africa. South. Afr. J. Infect. Dis. 2016, 31, 84-90.

26. Gottlieb, T.; Nimmo, G.R. Antibiotic resistance is an emerging threat to public health: An urgent call to action at the Antimicrobial Resistance Summit. Med. J. Aust. 2011, 194, 281-283. [CrossRef]

27. Zaidi, S.F.; Alotaibi, R.; Nagro, A.; AlSalmi, M.; Almansouri, H.; Khan, M.A.; Khan, A.; Memon, I. Knowledge and Attitude Towards Antibiotic Usage: A Questionnaire-Based Survey Among Pre-Professional Students at King Saud bin Abdulaziz University for Health Sciences on Jeddah Campus, Saudi Arabia. Pharmacy 2020, 8, 5. [CrossRef] [PubMed]

28. Sun, Q.; Dyar, O.J.; Zhao, L.; Tomson, G.; Nilsson, L.E.; Grape, M.; Song, Y.; Yan, L.; Lundborg, C.S. Overuse of antibiotics for the common cold-attitudes and behaviors among doctors in rural areas of Shandong Province, China. BMC Pharmacol. Toxicol. 2015, 16, 1-6. [CrossRef] [PubMed] 
29. Hayat, K.; Li, P.; Rosenthal, M.; Ji, S.; Fang, Y. Community pharmacists' knowledge about antibiotics and their perceptions of and participation in community-based antimicrobial stewardship programmes: A cross-sectional survey from central China. Lancet 2019, 394, S68. [CrossRef]

30. Li, P.; Hayat, K.; Shi, L.; Lambojon, K.; Saeed, A.; Aziz, M.M.; Liu, T.; Ji, S.; Gong, Y.; Feng, Z.; et al. Knowledge, Attitude, and Practices of Antibiotics and Antibiotic Resistance Among Chinese Pharmacy Customers: A Multicenter Survey Study. Antibiotics 2020, 9, 184. [CrossRef] [PubMed]

31. Ali, M.; Abbasi, B.H.; Ahmad, N.; Fazal, H.; Khan, J.; Ali, S.S. Over-the-counter medicines in Pakistan: Misuse and overuse. Lancet 2020, 395, 116. [CrossRef]

32. Saleem, Z.; Hassali, M.A.; Godman, B.; Fatima, M.; Ahmad, Z.; Sajid, A.; Rehman, I.U.; Nadeem, M.U.; Javaid, Z.; Malik, M.; et al. Sale of WHO AWaRe groups antibiotics without a prescription in Pakistan: A simulated client study. J. Pharm. Policy Pr. 2020, 13, 1-8. [CrossRef] [PubMed]

33. Hayat, K.; Rosenthal, M.; Gillani, A.H.; Chang, J.; Ji, W.; Yang, C.; Jiang, M.; Zhao, M.; Fang, Y. Perspective of Key Healthcare Professionals on Antimicrobial Resistance and Stewardship Programs: A Multicenter Cross-Sectional Study from Pakistan. Front. Pharmacol. 2020, 10, 1520. [CrossRef]

34. Asghar, S.; Atif, M.; Mushtaq, I.; Malik, I.; Hayat, K.; Babar, Z.-U.-D. Factors associated with inappropriate dispensing of antibiotics among non-pharmacist pharmacy workers. Res. Soc. Adm. Pharm. 2020, 16, 805-811. [CrossRef]

35. Dulon, M.; Peters, C.; Schablon, A.; Nienhaus, A. MRSA carriage among healthcare workers in non-outbreak settings in Europe and the United States: A systematic review. BMC Infect. Dis. 2014, 14, 363. [CrossRef]

36. Da Silva, L.S.; Andrade, Y.M.S.; Oliveira, A.C.; Cunha, B.C.; Oliveira, E.G.; Cunha, T.S.; Mafra, S.S.; Almeida, J.B.; Carvalho, S.P.; Nascimento, F.S.; et al. Prevalence of methicillin-resistant Staphylococcus aureus colonization among healthcare workers at a tertiary care hospital in northeastern Brazil. Infect. Prev. Pr. 2020, 2, 100084. [CrossRef]

37. Joachim, A.; Moyo, S.J.; Nkinda, L.; Majigo, M.V.; Rugarabamu, S.; Mkashabani, E.G.; Mmbaga, E.J.; Mbembati, N.; Aboud, S.; Lyamuya, E.F. Nasal Carriage of Methicillin-Resistant Staphylococcus aureus among Health Care Workers in Tertiary and Regional Hospitals in Dar es Salam, Tanzania. Int. J. Microbiol. 2018, 2018, 5058390-5058397. [CrossRef]

38. Wilson, H.L.; Daveson, K.; Del Mar, C.B. Optimal antimicrobial duration for common bacterial infections. Aust. Prescr. 2019, 42, 5-9. [CrossRef] [PubMed]

39. Zilahi, G.; McMahon, M.A.; Póvoa, P.; Martin-Loeches, I. Duration of antibiotic therapy in the intensive care unit. J. Thorac. Dis. 2016, 8, 3774-3780. [CrossRef]

40. Lucet, J.-C.; Nicolas-Chanoine, M.-H.; Roy, C.; Riveros-Palacios, O.; Diamantis, S.; Le Grand, J.; Papy, E.; Rioux, C.; Fantin, B.; Lefort, A.; et al. Antibiotic use: Knowledge and perceptions in two university hospitals. J. Antimicrob. Chemother. 2011, 66, 936-940. [CrossRef] [PubMed]

41. Hayat, K.; Rosenthal, M.; Zhu, S.; Gillani, A.H.; Chang, J.; Bogale, A.A.; Kabba, J.A.; Yang, C.; Jiang, M.; Zhao, M.; et al. Attitude of clinicians towards hospital-based antimicrobial stewardship programs: A multicenter cross-sectional study from Punjab, Pakistan. Expert Rev. Anti-Infect. Ther. 2019, 17, 661-669. [CrossRef] [PubMed]

42. Kufel, W.D.; Jeffres, M.N.; MacDougall, C.; Cho, J.C.; Marx, A.H.; Williams, D.M. Antimicrobial stewardship education in US colleges and schools of pharmacy. J. Antimicrob. Chemother. 2018, 73, 2252-2258. [CrossRef]

43. Khan, Y.; Kritiotis, L.; Coetzee, R.; McCartney, J.; Boschmans, S.-A. An Antimicrobial Stewardship Curriculum to Incorporate in the South African Bachelor of Pharmacy Degree Program. Am. J. Pharm. Educ. 2019, 84, ajpe7669. [CrossRef]

44. McNulty, C.; Cookson, B.D.; Lewis, M.A.O. Education of healthcare professionals and the public. J. Antimicrob. Chemother. 2012, 67, i11-i18. [CrossRef]

45. Majumder, A.A.; Singh, K.; Hilaire, M.G.-S.; Rahman, S.; Sa, B.; Haque, M. Tackling Antimicrobial Resistance by promoting Antimicrobial stewardship in Medical and Allied Health Professional Curricula. Expert Rev. Anti-Infect. Ther. 2020, 18, 1245-1258. [CrossRef]

46. Kandeel, A.; Palms, D.L.; Afifi, S.; Kandeel, Y.; Etman, A.; Hicks, L.A.; Talaat, M. An educational intervention to promote appropriate antibiotic use for acute respiratory infections in a district in Egypt-pilot study. BMC Public Health 2019, $19,498$. [CrossRef]

47. Gajdács, M.; Paulik, E.; Szabó, A. Knowledge, attitude and practice of community pharmacists regarding antibiotic use and infectious diseases: A cross-sectional survey in Hungary (KAPPhA-HU). Antibiotics 2020, 9, 41. [CrossRef] [PubMed]

48. Nisabwe, L.; Brice, H.; Umuhire, M.C.; Gwira, O.; Harelimana, J.D.D.; Nzeyimana, Z.; Sebatunzi, O.R.; Rusingiza, E.; Hahirwa, I.; Muvunyi, C.M. Knowledge and attitudes towards antibiotic use and resistance among undergraduate healthcare students at University of Rwanda. J. Pharm. Policy Pr. 2020, 13, 1-8. [CrossRef] [PubMed]

49. Daina, L.G.; Sabău, M.; Daina, C.M.; Neamțu, C.; Tit, D.M.; Buhaș, C.L.; Bungau, C.; Aleya, L.; Bungau, S. Improving performance of a pharmacy in a Romanian hospital through implementation of an internal management control system. Sci. Total. Environ. 2019, 675, 51-61. [CrossRef] [PubMed] 